\title{
45 Yaş ve Üzeri Kişilerin Yaşlılık Tutumlarının ve Yaşam Kalitesi Algılarının Sosyodemografik Özelliklere Göre İncelenmesi
}

\author{
The Examination of 45-Year-Old and Older People's Attitudes Toward Old Age and Quality of Life in Terms of \\ Sociodemographic Characteristics
}

Hanife Göktaş ${ }^{1}$ (D) , ERdem Özkan ${ }^{2}$ (D) , Abdullah OKumuş ${ }^{3}$ (iD

Ö Z

Bu çalışmanın amacı, 45 yaş üstü kişilerin yaşlılık dönemine ilişkin tutumlarındaki ve yaşam kalitelerindeki farklılaşmaların sosyodemografik özellikler çerçevesinde değişimini incelemektir. Çalışmada sosyodemografik özellikler olarak cinsiyet, yaşam evresi, yaş grubu, eğitim düzeyi, medeni durum, çocuk sahibi olma, gelir durumu, meslek, genel sağlık durumu, kronik hastalığa sahip olma durumu, yaşam memnuniyeti ve geleceğe/yaşlılığa yönelik yatırım planı olma durumu değişkenleri belirlenmiştir. Ankara'da gerçekleştirilen çalışmalarda yüz yüze anket yöntemi kullanılarak 408 kişiden veri toplanmıştır. Verilerin analizinde Mann Whitney U ve Kruskal Wallis H testi kullanılmıştır. Çalışmanın sonucunda, kişilerin yaşlılığa ilişkin tutumlarının cinsiyet ve çocuk sahip olma değişkenleri haricindeki diğer sosyodemografik özelliklere göre farklılık gösterdiği bulunmuştur. Öte yandan, kişilerin yaşam kalitelerinin ise çocuk sahibi olma değişkeni haricindeki diğer sosyodemografik özelliklere göre farklılaştı̆̆ı tespit edilmiştir.

Jel Sinıflaması: M30, J19.

Anahtar Kelimeler: Aktif Yaşlanma, Yaşlılık Tutumu, Yaşam Kalitesi.

\section{A B S T R A C T}

This study aims to investigate the changes in attitudes toward old age and the quality of life of people aged 45 and older within the framework of sociodemographic factors. In the study, gender, life stage, age group, education level, marital status, having a child, income status, occupation, general health status, having a chronic disease, life satisfaction, and having an investment plan for the future/old age were determined as sociodemographic factors. During the research carried out in Ankara, the data were collected from 408 people using a face-to-face survey method. Mann Whitney U and Kruskal Wallis $\mathrm{H}$ tests were used for data analysis. In conclusion, attitudes toward old age differs according to other sociodemographic characteristics, except for the variables of gender and having children. On the other hand, the quality of life differs according to other sociodemographic characteristics, except for having children.

Jel Classification: M30, J19.

Keywords: Active Ageing, Attitude toward Old Age, Quality of Life.

\section{DOI: 10.47934/tife.10.02.04}

*Bu çalışma, Hanife Göktaş tarafından hazırlanan "Ankara ilinde yaşayan 45 yaş ve üzeri kişilerin yaşlılık beklenti ve algılarının sosyo-demografik özellikler itibariyle incelenmesi” başlıklı yüksek lisans tezinden türetilmiştir.

1. Bilim Uzmanı, İstanbul, Türkiye.

ORCID: 0000-0003-3362-7443

2. Dr. Öğr. Üyesi, İstanbul Üniversitesi, İşletme Fakültesi, İstanbul, Türkiye.

ORCID: 0000-0003-1648-3732

3. Prof. Dr., İstanbul Üniversitesi, İşletme Fakültesi, İstanbul, Türkiye.

ORCID: 0000-0002-7556-384X

\section{SORUMLU Yazar / CoRRESPONDING AUTHOR}

Erdem Özkan,

Dr. Öğr. Üyesi, İstanbul Üniversitesi, İşletme Fakültesi, İstanbul, Türkiye.

E-mail: erdem.ozkan@istanbul.edu.tr

$\begin{array}{ll}\text { BAŞVURU/SUBMITTED: } & 12.08 .2021 \\ \text { REVIZYON TALEBI/ } & \\ \text { REVISION REQUESTED: } & 20.10 .2021 \\ \text { SON REVIZYON/ } & \\ \text { LAST REVISION : } & - \\ \text { KABUL / ACCEPTED: } & 02.11 .2021\end{array}$

Atıf / Citation: Göktaş, H., Özkan, E., Okumuş, A. (2021). 45 Yaş ve Üzeri Kişilerin Yaşlılık Tutumlarının ve Yaşam Kalitesi Algılarının Sosyodemografik Özelliklere Göre İncelenmesi. Trakya Üniversitesi İktisadi ve İdari Bilimler Fakültesi e-Dergi, 10(2), 112129, https://doi.org/10.47934/tife.10.02.04 


\section{Giriş}

Gençlik ve ilk yetişkinlik dönemlerinde ileriye dönük tasavvurlar/hayaller içerisinde pek yer almayan yaşlılık, orta yaş ve özellikle orta yaşın sonlarına doğru çok da uzak olmayan bir dönem olarak algılanıp gelecek kaygılarına basamak olmaya başlar. Günümüzde pek çok yaşlı, kendisini gençliğinde düşündüğü ve düşlediği koşullardan çok daha farklı bir konumda bulabilmektedir (Hablemitoğlu ve Özmete 2010). "Yaşlıık" en genel tanımıyla yaşam süresinde gelişme ve olgunlaşmayı takip eden, genetik yapı ve çevre arasındaki etkileşimin en üst düzeyde görüldüğü fizyolojik ve ruhsal değişimlerin ortaya çıktığı bir dönem olarak ifade edilebilir (Akçay, 2013). İnsan hayatının son dönemi olan bu dönem, özellikle, içinde yaşadığımız yüzyılda önemli bir problem olarak ele alınmaya başlamıştır. Daha önceki dönemlerde edebiyat ve sanatın konusu olan yaşlılık, günümüzde sağlıktan ekonomiye, sosyolojiden teknolojiye kadar birçok alanın üzerinde çalıştığı bir konu haline gelmiştir.

Yaşlılık çoğu zaman kronolojik yaş temelinde ele alınmaktadır. Bu durum yaşlılığın başlangıcı ve yaşlılık tanımına dair tartışmalara neden olmuştur. Yaşılık başlangıç yaşının farklıığı hala devam eden bir karmaşadır. Birleşmiş Milletler raporlarında (UN, 2015; 2017) 65 yaş ve üstü grubundaki bireyler "yaşlı" kategorisinde değerlendirilmektedir. Dünya Sağlık Örgütü'nün raporlarında (WHO, 2015) ise 60 yaş ve üzeri grubun "yaşlı" olarak değerlendirildiği görülmektedir. Dünya Sağlık Örgütü'nün gelişmiş ülkelere ilişkin analizlerinde ise "65 yaşı" kullanıyor olması dikkati çekmektedir. Yaşlılık başlangıç yaşında bu şekilde farklılar olmasının nedeni dünya üzerinde her bölgede aynı yaşam koşullarının olmaması dolayısıyla bölgesel yaşam beklentisi sürelerinin farklılaşması ve aynı kronolojik yaşın farklı anlamlar ihtiva etmesi olarak görülebilir. Kişinin yaşadığı toplumun refah düzeyi ve çevresel şartları, kişinin getirdiği kalıtımsal özellikler, bireyin şimdiye kadar ki yaşam deneyimleri (olumlu, olumsuz), etnik kökeni, cinsiyeti, ekonomik şartları vs. bu farklılığın nedenleri arasında sayılabilir. Örneğin Afrika ülkelerinde yaşam beklentisi süresi çok daha düşük olup, 60 yaş yaşamın son dönemlerini ifade etmektedir. Avrupa ülkelerinde ise 60 yaşın anlamı orta yaşın son dönemleri olarak anlaşılmaktadır. Dünya Sağlık Örgütü’nün bu noktada genellenebilir kullanıma uygun olarak 60 yaşı baz aldığı düşünülebilir. Bu çalışmada ise, Tüik verileri göz önünde bulundurularak 45 yaş ile 64 yaş arası dönem orta yaş ve yaşlılık başlangıç yaşı ise 65 olarak alınmıştır (TÜiK, 2018).

Yaşlılık algısı, bireyin çocukluk, gençlik, yetişkinlik dönemlerini yaşama biçimine, içinde bulunduğu koşullara bağlı olarak değişkenlik göstermekle beraber son dönemlerde "yaşam kalitesi" kavramı bu algı ile birlikte ele alınmaktadır. "Yaşam kalitesi" kavramı, kişinin yaşamının kalitesine ilişkin değerlendirmeleri içermektedir ve bu değerlendirmeler kişinin geliri, sağlık durumu, aile hayatı, sosyal hayatı, yaşadığı çevre gibi birçok unsurun etkileşimi ile ortaya çıkmaktadır (Gill ve Feinstein 1994; OECD, 2016). Yaşam kalitesi, en basit biçimde bireyin yaşamının tümüyle iyi gittiğine ilişkin hissettiği öznel duyguların toplamı olarak ifade edilmektedir (Hablemitoğlu ve Özmete, 2010). Eser, Saatli Gerçeklioğlu, Eser, Fidaner, Baysan, Pala ve Dündar (2011) yaşlıların yaşlıııkla ilgili olumlu algılarının ömürlerini uzattığı yönünde çeşitli çalışmalarda bulguların yer aldığını belirtmektedir. Bu çalışmalarda (Levy, Ashman ve Dror, 2000; Levy, Hausdorff, Hencke ve Wei, 2000; Levy, Slade, Kunkel ve Kasl, 2002) olumlu yaşlılık algısının yaşam süresi üzerinde cinsiyet, sosyo-ekonomik durum, yalnızlık ve işlevsel sağlık durumu değişkelerinden daha etkili bir değişken olduğu gösterilmiştir. Bu etki olumlu sağlığı geliştirme davranışları (sağlıklı beslenme, spor yapma, sigara kullanmama gibi) ile görünür hale gelmektedir (Eser vd., 2011). Her anlamda sağlıklı bir yaşlanmanın öncülü sayılan "yaşam kalitesi algısı" ve bu algı ile şekillenen "tutumlar", bireyleri yaşlanma sürecine hazırlayan unsurlardır.

Yaşam dönemleri açısından iki demografik grubun (orta yaşlı ve yaşlı), yaşlılık ile ilgili değerlendirmelerinin alt yaş gruplarından farklılık göstermesi muhtemel bir durumdur. Örneğin yapılan araştırmalarda 44 yaş ve altındaki bireylerin, yaşam kalitesi ve sağlık açısından, üst yaş grubundaki 
bireylere kıyasla çok daha farklı değerlendirmelerde bulunduklarını göstermiştir (Eser, Fidaner, Fidaner, Eser, Elbi ve Göker, 1999). 44 yaş ve altındaki bireyler ile üst yaş grubu bireyler arasındaki farklılık kırılma noktası olarak yaşın kritik önemine işaret etmektedir. Buradan hareketle bu çalışmada yaşam dönemlerine göre orta yaş ve yaşı kategorilerinde ele alınabilecek bireylerin yaşlılık tutumları ve yaşam kalitelerine odaklanılmıştır.

Kamu kurumları başta olmak üzere yaşlı bireylere hizmet sağlayan tüm taraflar, geliştireceği plan ve programlarda hangi hususlara odaklanacağını doğru belirlemek durumundadır. Bu sayede yaşıların yaşam kalitesini iyileştirmeye yönelik daha etkili politikalar geliştirebilmeleri ve hizmet sağlayabilmeleri mümkün olabilecektir. Bu düşünceyle bu çalışmada, bireylerin yaşlılık tutumlarını ve yaşam kalitelerini etkileyen unsurları belirleyerek söz konusu ihtiyacın karşılanmasına yönelik katkı sağlanabileceği değerlendirilmiştir. Bu bağlamda bu çalışma, her bireyin temel özelliklerinden olan sosyodemografik özelliklerin bireylerin yaşlılık tutumlarını ve yaşam kalitelerini etkileyen unsurlar arasında yer alıp almadığı sorusundan yola çıkılarak hazırlanmıştır.

Sonuç olarak bu çalışmada, 45 yaş üzeri bireylerin yaşlılık tutumu ve yaşam kalitesi temelinde yaşlılık algı ve beklentilerinin sosyodemografik özelliklere göre değişkenlik gösterip göstermediğini ortaya koymak amaçlanmıştır.

\section{Kavramsal Çerçeve}

Bu bölümde bireylerin yaşlılık süreçleri ve yaşıılığa ilişkin algı ve beklentileri yaşlanma kavramı temelinde ele alınmıştır. Bu bağlamda literatürde bu çalışmanın konusu ve amacı ile ilintili olarak yaşlanma kavramı, yaşlılık dönemleri ve yaşlanma ile ilişkisi, aktif yaşlanma ve yaşam kalitesi kavramları açıklanmıştır.

\subsection{Yaşlanma ve Yaşlılık}

Yaklaşım ve anlayış farklılıkları nedeniyle yaşlanmanın üzerinde herkesin tümüyle ittifak ettiği tek bir tanım bulunmamaktadır. Yaşlanmayı, "biyolojik olarak döllemenin meydana geldiği andan yaşamın sona erdiği ana kadar devam eden çocukluk, gençlik, yetişkinlik ve yaşlılık dönemlerinin tümünü kapsayan biyo-psiko-sosyal bir değişim ve gelişim süreci” olarak özetleyen Danış (2004), psikososyal özelliklerin, sağlık durumlarının, yaşam tecrübelerinin ve içinde bulunulan koşulların bireyin yaşlanma sürecinin seyri ile direkt ilintili olduğuna dikkati çekmektedir. Akçay (2013) yaşlanma olgusunu, kronolojik, biyolojik, psikolojik ve toplumsal olmak üzere dört ayrı açıdan ele almanın, kavramın daha iyi anlaşımasını sağlayacağına değinerek, insanların yaşadıkları toplumdaki yaşlanma ve yaşlılık ile ilgili değerlerden etkilenmelerini toplumsal yaşlanma biçiminde değerlendirmesi gerektiğine dikkati çekmektedir. Arslan (2015)'a göre de yaşlanma, canlı bir organizmadaki eskimenin, ölüme gidiş sürecinin, yaşlılığı dışa vuran olguların tümünü ifade etmektedir. Ona göre tabii ve kaçınılmaz yaşlanma süreci, kişinin kalıtımsal özellikleri, beslenmesi, yaşadığı çevre koşulları, sosyal ve kültürel edinimlerine göre, az veya çok sorunlu, erken veya geç sorunlu olarak yaşanır. İnsan yaşamının iki bölümden oluştuğunu ifade eden Arslan (2015); doğum, büyüme ve gelişme evrelerini içeren kısmı "gençlik", hücrelerin fonksiyonlarının gerilediği kısmı da "yaşlılık" olarak niteler.

Yaşlanma kavramı ile yaşlılık kavramı genellikle birbirine karıştırılabilmektedir. Yaşlanma, yaşam boyu devam eden hem gelişmeyi hem de gerilemeyi içinde barındıran bir süreçtir. Canatan (2008), "yaşlanma bir süreç iken, yaşlılık bir dönemi ifade eder" şeklinde özetlemiştir. Tufan (2015) ise "yaşlanma ve yaşlılık arasında ayrım yapan gerontoloji, yaşlanmayı bir süreç, yaşlılığı bu sürecin doğurduğu sonuç olarak kabul eder" sözleri ile Canatan (2008)'ın bu ifadelerini desteklemiştir. Yaşlılık kavramı, yaşlanma kavramına kıyasla göreceli biçimde de olsa daha dar kapsamlıdır. Yaşlanma ile yaşlııık arasında süreç bakımından, yani meydana geliş zamanları açısından da birtakım farklılıklar vardır. Yaşlanma süreci,

Trakya Üniversitesi Iktisadi ve İdari Bilimler Fakültesi e-Dergi, 10, 2021/2, s. 112-129 
yaşlılıktan daha önce başlayan bir süreçtir. Ayrıca yaşlanma kavramı, fiziksel ve zihinsel yeterliliklerin kaybından öte bu alanlardaki gelişmeleri de kapsamaktadır (Akçay, 2013).

Genelde durağan bir yapıda olan yaşlılık süreci, fizyolojik, psikolojik ve toplumsal yaşamdaki birtakım edinimlerinin yitirilmesi ve yaşamın pek çok alanında kayıplarla karşılaşıması olağan bulunan bir niteliğe sahiptir (İçli, 2016). Bu kayıplar, kişinin bir yakınını kaybetmesinden işini, fiziksel gücünü yitirmesine kadar uzanan geniş bir yelpaze teşkil etmektedir. Yaşlılık kendi başına bir dönemden çok kendinden önceki dönemlerle bağlantısı olan ve canlı vücudu için değişmenin devam ettiği bir dönemdir. Bu dönemde meydana gelen değişimler genellikle olumsuz bir nitelik taşımaktadır. İnsan vücudundaki yetilerin zayıflaması, bellek ve algılamada sorunlar yaşama, sosyal yaşamdan kopma ve izole olmalar genellikle yaşlılık dönemindeki bireylerin karşılaştığı ve onlara olumsuz etki eden problemler olarak nitelendirilmektedir. Kayıp ve bazı gerileme belirtileri ortaya çıktığı, ölüme daha yakınlaşıldığı bir dönem olarak algılanan yaşlılıkta, aslında bireylerin gelişimleri de devam etmektedir. Birbiriyle zıt özelliklere sahip olan bu sürecin sağlıklı bir şekilde ele alınıp değerlendirilmesi, yaşlı bireylerin hem fizyolojik hem de psikolojik sağlıklarına olumlu etki edecektir (Koç, 2002). Bireylerin, yaşlanmanın psikolojik boyutlarını göz önünde bulundurarak, yaşlanma sürecinde elde edebileceği tıbbi, ekonomik ve sosyal olanaklar çerçevesinde daha sağlıklı bir yaşılıık dönemi geçirebilmesi mümkündür (Yoğurtçu, 2019).

\subsection{Yaşlanma ve Orta yaş}

Yaşlılığın bir öncesini teşkil eden orta yaş döneminin nerede başlayıp nerede bittiği hususunda araştırmacılar arasında tam bir ittifak yoktur. Orta yaşlar, çoğu toplumda kişilerin kişisel ve sosyoekonomik yönden en üst seviyeye eriştikleri yaşlardan başlayıp iş veya görevlerini nihayete erdirip emekli oldukları yaşlara kadar uzanmaktadır. Onur (1986), orta yaşları insanın yaşamında bağımsızlığını elde ettiği 35 yaş civarından başlatarak birçok bakımdan kayıplar yaşadığı ve de gerilemelerin başladığı 65 yaşına kadar uzadığı görüşündedir (Onur, 1986). Uysal (2006) ise farklı çalışmalarda orta yaş döneminin 30-55 yaş arası, 40-60 arası gibi farklı şekillerde ele alındığını belirtmektedir (Uysal, 2006). Bu çalışmada ise TÜik (2018) ve Dünya Sağıık Örgütü raporları (WHO, 2015) paralelinde 45-64 yaş arası orta yaş olarak ele alınmaktadır.

Onur (1986)'a göre orta yaş için belirlenen yaş aralıkları, neticede yapay bir sınırlamadır. Nitekim, söz konusu sınırlar dahilinde yer alan, ancak hem kişilik hem de ekonomik açıdan bir ergen kadar bunalımlı olan birçok bireyin mevcudiyeti, orta yaş sınırlarının belirsizliğini artırmaktadır. illhan (2013), orta yaşın sınırlarının nerde başlayıp nerde bittiğini biyolojik saatimizin değil, toplumsal saatimizin belirlediğini vurgulamaktadır. Ona göre, orta yaşın sınırları da, sosyal kurallar içinde tanımlanan "yaşa uygun" davranışlarda gizlidir (illhan, 2013). Bu dönemde iş, insan hayatında merkezi öneme sahiptir. Bu çağ, kişinin aynı zamanda hayatın anlamını da sorgulanmaya başladığı bir dönemdir (Santrock, 2017).

Orta yaş grubu insanı, toplum içinde karar verme yetisi bakımından, diğer yaş gruplarından daha avantajlı, daha üstün konumdadır. Bu grup sosyal yaşamın her alanında "hakim sınıf" rolünü oynamaktadır (Kılıç, 2013). Genel özellikleri dikkate alınırsa orta yaş döneminin bireyler için düşüşe geçişin ilk izlerini taşıdığı görülmektedir. Ergenlik dönemiyle beraber vücutta meydana gelen ilerlemeler ve gelişmeler yerini yavaş yavaş çeşitli fonksiyonlarda kayıplara bırakacaktır. Biyolojik olarak bir gerileme söz konusu olsa da bireylerin sosyal yaşamlarının zirvede olduğu görülmektedir. Mesleki anlamda tepe noktasında bulunan bireyler aile yaşamlarında da hareketli zamanları yaşamaktadır (Onur, 1986).

\subsection{Yaşlanma Türleri ve Aktif Yaşlanma}

Her canlı için kaçınılmaz bir süreç olan yaşlanma, kişiden kişiye farklıık gösterebilmektedir. Yaşlanma süreci yalnızca biyolojik faktörlerden değil çevresel, kültürel, sosyal faktörlerden de etkilenebilmektedir. Bu etkilenme bireylerin cinsiyetlerine göre farklılık gösterebildiği gibi tek bir bireyin kendi vücudundaki organlarının arasında da değişim farklılıklarının bulunması mümkündür (Akın, Gültekin

Trakya Üniversitesi Iktisadi ve İdari Bilimler Fakültesi e-Dergi, 10, 2021/2, s. 112-129 
ve Koca, 2002). Yaşlanma kavramının farklı boyutlarını dikkate alarak yapılan tanımlamalardan hareketle, yaşlanma çeşitlerini biyolojik yaşlanma (Akçay, 2013), psikolojik yaşlanma (Akçay, 2013), kronolojik yaşlanma (Şentürk, 2018), ekonomik yaşlanma (Yıldız, Ömeroğlu ve Terim, 2017), sosyal yaşlanma (Karataş, 1990; Şentürk, 2018) şeklinde sıralamak mümkündür.

Yaşlanma çeşitleri ile ilintili önemli bir üst bir başık olarak öne çıkan aktif yaşlanmayı ayrı ele almakta yarar bulunmaktadır. Aktif yaşlanma; bir başka deyişle sağlıklı yaşlanma, başarılı yaşlanma ve üretken yaşlanma şeklinde kullanılabilmektedir. Aktif yaşlanma, salt faal ve sağlıklı olarak değil, aynı zamanda ekonomik, sosyal, kültürel, manevi ve bireysel ilişkiler gibi toplumsal dinamiklere de katılmayı ifade etmektedir (Gündoğan, 2001).

Dünya Sağlık Örgütü aktif yaşlanmayı, insanların yaşlanma yolculuklarında; yaşam kalitesini artırmak için, sağlık, güvenlik ve topluma katılım fırsatlarının en üst seviyede sağlanma süreci şeklinde betimlemiş ve bunu tüm yaş grubu bireyler için bir hak olarak ifade etmiştir (WHO, 2002; Hablemitoğlu ve Özmete 2010). Aktif yaşlanmanın çıkış noktası sayılan ve ABD menşeli olan başarılı yaşlanma kavramı, orta yaşlılık dönemindeki faaliyetlerin yaşlılık döneminde de devam ettirilmesi olarak değerlendirilmiştir. (Çağlar, 2015).

Aktif yaşlanma süreci içerisinde değerlendirilen unsurlar fiziksel aktiflik, sosyal aktiflik, kültürel aktiflik, ekonomik aktiflik, manevi aktiflik ve yerel aktiflik olarak ifade edilebilir (WHO, 2002). Aktif yaşlanmada temel nitelik, bireylerin yalnızca fiziki açıdan iyilik halini değil aynı zamanda sosyo-kültürel ve ekonomik açıdan toplumsal süreçlere katılımını da ifade etmektedir. Gursoy-Cuhadar (2020), aktif yaşlanma yaklaşımının bireye ve devlete katkılarının mikro ve makro açıdan ayrı ayrı ele alınabileceğini de belirtmektedir. Buna göre aktif yaşlanma yaklaşımı bir yandan bireylerin kendilerini daha sağlıklı ve mutlu hissetmesini sağlarken, bir yandan da sosyal güvenlik açısından devlete yük olmamayı hedeflemektedir (Gursoy-Cuhadar, 2020). Aktif yaşlanma sürecinde, bu kapsamda değerlendirilen bireylerin psikolojik, fizyolojik ve sosyal açıdan iyiliklerinin temini ile istek ve ihtiyaçlarına yönelik bakım hizmetlerinin yapılması da desteklenmektedir (Çolak ve Özer 2015).

\subsection{Yaşam Kalitesi}

Aktif yaşlanmada önemli bir kavram olarak öne çıkan yaşam kalitesi kavramı, genel olarak bireylerin sağlık durumları başta olmak üzere yaşamının bütün alanlarına ilişkin algı ve tepkileri ifade etmektedir (Gill ve Feinstein, 1994). Dünya Sağlık Örgütü ise yaşam kalitesini bir bireyin yaşadığı kültür ve değer sistemleri bağlamında ve amaçlarına, beklentilerine, standartlarına ve kaygılarına bağlı olarak yaşamdaki konumlarına ilişkin algıları olarak tanımlamıştır (WHO, 1997). Bu tanım dışında yaşam kalitesi ile ilgili farklı tanımlamalarda literatürde yer almaktadır. Yaşam kalitesi ile ilgili yapılan farklı tanımlamalar olsa da bu tanımların bir takım ortak yönlerinin olduğu görülmektedir. Bu ortak özellikler (Cummins, 2005):

- Yaşam kalitesinin bir bütün olarak değerlendirilmesi,

- Yaşam kalitesinin kültürel ve evrensel değerlerden etkilenmesi,

- Değişkenlik gösterip ve zaman içerisinde değişebilmesi,

- Tek boyutlu olmayıp çok boyutlu olması,

- Bireysel faktörlerden olduğu kadar bireyin dışında gelişen faktörlerden de etkilenmesi,

- Değerlendirilmesinde nesnel ve öznel süreçlere ihtiyaç duyulması,

- Bireyin kendisine yetebilmesi, hayatının amacı ve aidiyet duygusu gibi unsurlardan doğrudan etkilenmesidir.

Trakya Üniversitesi Iktisadi ve İdari Bilimler Fakültesi e-Dergi, 10, 2021/2, s. 112-129 
Yaşam kalitesinin birtakım göstergeleri bulunmaktadır. Bu göstergeler yaşam kalitesinin değerlendirilmesi ve belirlenmesi için önemli görülmektedir. Ekonomik Kalkınma ve İşbirliği Örgütü (OECD) tarafından yapılan araştırmada yaşam kalitesinin göstergeleri konut, gelir, iş ve çalışma hayatı, topluluk, eğitim durumları, çevre, sivil katılım, sağlık, yaşam memnuniyeti, güvenlik, çalışma ve yaşam dengesi başlıklarında ele alınmıştır (OECD, 2016). Belirtilen bu konu alanları ülkelerin yaşam kalitesinin belirlenmesinde ve ülkelerarası karşılaştırmaların yapılmasında önemli rol oynamaktadır. Dolayısıyla yaşam kalitesi bireyler açısından ölçülü değerlendirildiği kadar ülkelerin genel profili açısından da yaşam kalitesinin değerlendirilmesi yapılmaktadır. Buna bağı olarak OECD tarafından düzenli olarak yapılan yaşam kalitesi araştırmasında (OECD, 2017) ülkelerin yaşam kalitesi düzeyleri belirlenmiş olup, araştırma yapılan ülkelerin genel yaşam kalitesi ortalamasının 6,2 olarak gerçekleştiği bulunmuştur. Bununla birlikte ülke sıralamalarında 38 ülke içerisinde yaşam kalitesi en yüksek olan ülkeler Norveç, Danimarka ve Avusturya iken, yaşam kalitesi sıralamasında son 3 ülke ise Türkiye, Meksika ve Güney Afrika'dır. Türkiye, yapılan araştırmaya göre 38 ülke sıralamasında 36. sırayı temsil etmektedir. Bu durum yaşam kalitesi açısından Türkiye'nin önemli geliştirmeler göstermesi gerektiğini de ortaya koymaktadır (OECD, 2017).

Yaşlılarda yaşam kalitesinin artması yaşamdan duyulan memnuniyeti arttırmaktadır (Şahin, Özer ve Yanardağ, 2019). Bu açıdan bireylerin yaşam kalitesi algılamalarını şekillendiren hususların açığa çıkarılması önem taşımaktadır. Bireylerin yaşam kalitesi algılamalarının değerlendirilmesi ise bireyin hayattan beklentilerinin karşılaştırmalı değerlendirmesine ve şu anda içinde bulunduğu durumun gerçekliğine bağı olduğu için çok karmaşık bir süreçtir (Saha, Basu ve Pand, 2020). Yaşam kalitesinin değerlendirilmesinde yalnızca yaşamanın bir bölümüne değil bütün alanlarına bütüncül bir bakış açısıyla yaklaşmak gerekmektedir. Bununla birlikte yaşamın iyileştirilmesine katkı sağlayan faktörler birlikte değerlendirilmelidir (Veenhoven, 2013).

Yaşam kalitesini etkileyen sağlık, barınma, yaş, sosyal ekonomik faktörler, benlik algısı, fiziksel aktiviteler, duygusal durum, yaşam memnuniyeti ve yaşam deneyimleri gibi birçok faktör bulunmaktadır. Yaşam kalitesini etkileyen çok sayıda faktör olmasına rağmen bunların herkes tarafından kabul edilen ortak bir sınıflandırması yapılamamıştır. Bunda yaşam kalitesinin bireylere, bireysel özelliklere, bölgesel ve ulusal özelliklere göre de farklılıklar göstermesi etkili olmaktadır. Bununla birlikte yaşam kalitesini etkileyen cinsiyet, yaş, eğitim durumu, gelir düzeyi, medeni durum gibi bazı sosyodemografik özellikler öne çıkmaktadır (Altıparmak ve Eser, 2007; Bingefors ve Isacson, 2004; Boylu ve Paçacıoğlu, 2016; Dumuid vd., 2017; Karadamar, Yiğit ve Sungur, 2014; Miller ve Dishon, 2006; Sözen, Çolak ve Ersoy, 2020; Top, Eriş ve Kabalcıoğlu, 2012). Bu değişkenler yaşam kalitesinin hem belirlenmesinde hem de yaşam kalitesinin farklı gruplar açısından karşılaştırılmasında kullanılan önemli ölçütlerden bazılarıdır. Dolayısıyla bu değişkenler yaşam kalitesinde temel faktörleri ifade etmektedir.

\section{Yöntem}

Bu çalışmada, yaşlılık tutumu ve yaşam kalitesi çerçevesinde 45 yaş üstü bireylerin yaşıılığa dair algılarının ve beklentilerinin ortaya konulması ve sosyodemografik özelliklere göre farklılıklarının belirlenmesi amaçlanmıştır. Yaşılığa ilişkin algı ve beklenti durumlarını temsilen "yaşlılık tutumu" ve "yaşam kalitesi" değişkenleri araştırma kapsamına eklenmiştir. Sosyodemografik özellikleri temsilen ise araştırmanın amacına uygun olacak şekilde; "cinsiyet", "yaşam evresi", "yaş grubu", "eğitim düzeyi", "medeni durum", "çocuk sahibi olma", "gelir durumu”, "meslek", "genel sağlık durumu”, "kronik hastalığa sahip olma durumu", "yaşam memnuniyeti" ve "geleceğe/yaşlılığa yönelik yatırım planı olma durumu" değişkenleri araştırma kapsamına dahil edilmiştir.

Araştırmanın amacı doğrultusunda araştırmanın ana hipotezleri şu şekilde belirlenmiştir.

- Hipotez 1: 45 yaş üstü bireylerin yaşlılık tutumları sosyodemografik özelliklere göre farklılık göstermektedir.

Trakya Üniversitesi Iktisadi ve Idari Bilimler Fakültesi e-Dergi, 10, 2021/2, s. 112-129 
- Hipotez 2: 45 yaş üstü bireylerin yaşam kaliteleri sosyodemografik özelliklere göre farklılık göstermektedir.

Araştırma ana hipotezlerinin değerlendirilmesi sürecinde, araştırma kapsamında belirlenen sosyodemografik özelliklerin her biri için ayrı ayrı alt hipotezler oluşturulmuş ve bu alt hipotezlerin uygunluğu test edilmiştir.

Araştırmada yaşlılık tutumu değişkenini ölçmek için Eser vd. (2011) tarafından Türkiye koşullarına uyarlanan "Avrupa Yaşlanma Tutumu Anketi (AYTA-TR)" kullanılmıştır. Bu ölçek beşli likert tipi 24 ifade ve 3 alt boyuttan (psikososyal kayıp, bedensel değişim, psikososyal gelişim) oluşmaktadır (Eser vd., 2011). Yaşam kalitesi değişkenini ölçmek için ise Türkiye'deki çalışmaları Eser, Saatli, Eser, Baydur ve Fidaner (2010) tarafından geliştirilen "Dünya Sağlık Örgütü Yaşam Kalitesi Formu (WHOQOL-OLD)" kullanılmıştır. Bu ölçek beşli likert tipi 24 ifade ve 6 alt boyuttan (duyusal işlevler, özerklik, geçmiş, bugün, gelecek faaliyetleri, sosyal katılım, ölüm ve ölmek, yakınlık) oluşmaktadır (Eser vd., 2010).

Araştırmanın ana kütlesini Ankara'da yaşayan 45 yaş ve üzeri bireyler oluşturmaktadır. Araştırmanın Ankara ile sınırlandırımasında, bu ilde yaşayanların genel Türkiye profilini temsil edebilecek çeşitlilikte sosyodemografik özelliklere sahip bireyler olması durumu etkili olmuştur. Bu kapsamda araştırma Ankara'da, ilçe nüfuslarının oransal dağılımına göre belirlenen örneklem ile yürütülmüştür. Örneklem büyüklüğünün belirlenmesinde maksimum varyanslı bir dağılım gözetilmiş, hata duyarlılığı \%5 olarak dikkate alınarak \%95 güven seviyesinde değerlendirme yapılmış ve asgari örneklem büyüklüğü 384 olarak hesaplanmıştır (Kurtuluş, 2010). Bu doğrultuda, Ankara ilinde nüfusu 100 bin üstü 10 ilçede minimum 384 kişiye ulaşılması hedeflenmiş ve Ankara'nın yaş dağılımı dikkate alınarak kotalı bir örneklem hazırlanmıştır. Kotalama dışında hiçbir sistematizasyon gözetilmemiştir. Kota uygulamasına örneklemin ana kütleyi temsil gücünü arttırması ve genellemelere imkan verebilmesi için başvurulmuştur.

Yüz yüze anket yöntemi kullanılarak gerçekleştirilen veri toplama süreci sonunda 410 kişiye ulaşılmıştır. Yapılan kontroller sonrasında iki anket elenerek 408 anket analize tabi tutulmuştur. Araştırma katılımcılarının kişisel bilgileri Tablo 1'de özetlenmiştir.

Tablo 1: Araştırma Katılımcılarının Sosyodemografik Özellikleri $(n=408)$

\begin{tabular}{|c|c|c|c|}
\hline Değişken & Düzey & $n$ & $\%$ \\
\hline \multirow{2}{*}{ Cinsiyet } & Kadın & 176 & 43,1 \\
\hline & Erkek & 232 & 56,9 \\
\hline \multirow{4}{*}{ Yaş Grubu } & 45 - 54 yaş & 187 & 45,8 \\
\hline & 55 - 64 yaş & 120 & 29,4 \\
\hline & 65 - 74 yaş & 65 & 15,9 \\
\hline & 75 yaş ve üstü & 36 & 8,9 \\
\hline \multirow{4}{*}{ Medeni Durum } & Evli & 334 & 81,9 \\
\hline & Bekar & 8 & 1,9 \\
\hline & Dul & 52 & 12,8 \\
\hline & Boşanmış & 14 & 3,4 \\
\hline \multirow{3}{*}{ Çocuk Sahipliği } & Var & 391 & 95,8 \\
\hline & Yok & 12 & 2,9 \\
\hline & Cevap vermeyen & 5 & 1,3 \\
\hline \multirow{3}{*}{ Eğitim Düzeyi } & Mezun değil & 19 & 4,7 \\
\hline & İlkokul mezunu & 155 & 38,0 \\
\hline & Ortaokul mezunu & 45 & 11,0 \\
\hline
\end{tabular}




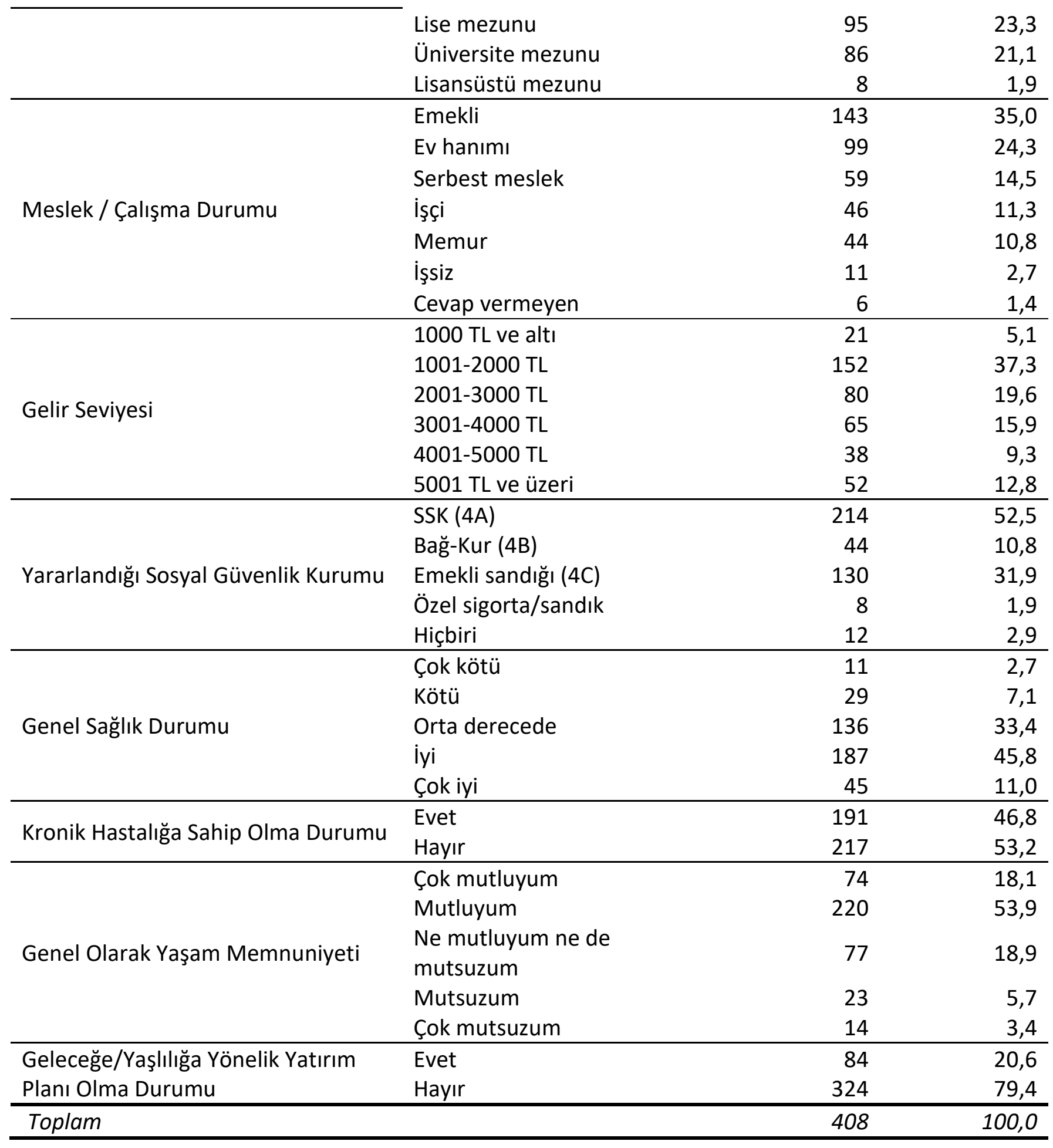

Araştırmanın hipotez testlerinde değerlendirilen "yaşam evresi" değişkeni, çalışmanın kavramsal çerçevesindeki açıklamalardan hareketle bireyin bulunduğu yaş grubu temelinde oluşturulmuştur. Buna göre yaş grubu 45-64 arasında olanlar "orta yaş", 65 ve üzerinde olanlar ise "yaşlı" grubunda ele alınmıştır.

\section{Bulgular}

Araştırmanın hipotezlerinin testi öncesinde araştırma değişkenlerinden yaşlılık tutumu ve yaşam kalitesi değişkenlerinin ölçümünde kullanılan ölçeklerin güvenirlikleri ve geçerlikleri değerlendirilmiştir. Araştırma ölçeklerinin güvenirlikleri içsel tutarlılık yöntemlerinden Cronbach Alpha ile değerlendirilmiştir. 
Güvenirlik analizinde, "Alpha" katsayısı (0,70 ve üzeri) düzeyde kabul edilebilir olmaktadır (Kurtuluş, 2010). Araştırmada ilk olarak yaşlılık tutumu ölçeğinin güvenirliğini açıklamak üzere iç tutarlılık analizine tabi tutulmuştur. Ölçek içerisinde olumlu ve olumsuz ifadeler bir arada yer alması nedeniyle; A3, A6, A9, A12, A15, A17, A20 ve A22 kodlu olumsuz tutum belirten ifadeler olumlu hale çevrilerek güvenirlik analizi gerçekleştirilmiştir. Yapılan analiz sonucunda Cronbach Alfa değeri $\alpha=0,723$ olarak hesaplanmıştır. Ancak yapılan değerlendirmede, A6 kodlu ifade silindiğinde ölçek güvenirlik değerinde anlamlı artış olacağı değerlendirilmiş ve bu ifade silinerek güvenirlik analizi yeniden gerçekleştirilmiştir. 23 ifadeli yeni durumda Cronbach Alfa değeri $\alpha=0,767$ olarak hesaplanmıştır. Sonuç olarak sonraki analizlerde ölçeğin 23 ifadeli hali kullanılmıştır. Araştırmada ikinci olarak yaşam kalitesi ölçeği güvenirlik analizine tabi tutulmuştur. Ölçek içerisinde olumlu ve olumsuz ifadeler bir arada yer alması nedeniyle; B1, B2, B6, B7, B8, B9 ve B10 kodlu olumsuz durum belirten ifadeler olumlu hale çevrilerek güvenirlik analizi gerçekleştirilmiştir. Yapılan analiz sonucunda Cronbach's Alfa değeri $\alpha=0,844$ olarak hesaplanmıştır. Bu değer ölçeğin çok iyi düzeyde güvenilir olduğuna gösterge sunmaktadır.

Araştırmada "yaşlılık tutumu" değişkenini ölçmek amacıyla kullanılan ölçeğin geçerliğini değerlendirmek için uygulanan keşfedici faktör analizi gerçekleştirilirken güvenirlik analizi sonucunda elde edilen 23 ifadelik yapı dikkate alınmıştır. Yaşlılık tutumu ölçeği için Barlett testi $p=0,000<0,05, K M O=0,769$ olarak bulunmuştur. Yapılan ilk keşfedici faktör analizi sonucunda altı faktör elde edilmiş ve bu faktörlerin toplam varyansın \%52,097'sini açıkladığı görülmüştür. Ancak elde edilen faktörler ve faktörler altındaki ifadeler değerlendirildiğinde, orijinal ölçek yapısındaki durumları bozan dağılımlar olduğu, bazı ifadelerin birden fazla faktörle yüksek seviyede ilişki gösterdiği, bazı ifadelerin ise düşük faktör yüküne sahip olduğu gözlenmiştir. Buna istinaden ölçek içerisinde yer alan A4, A8, A9, A10, A12, A15, A16 ve A19 kodlu ifadeler sırasıyla analiz dışı bırakılmış ve her seferinde keşfedici faktör analizi yinelenmiştir. Sonuç olarak 15 ifadeden oluşan yaşlılık tutumu ölçeği için dört alt faktörden oluşan bir yapının geçerli olduğu değerlendirilmiştir. Bu yapının toplam varyans açıklama oranının \%52,512 olduğu hesaplanmıştır. Elde edilen alt boyutların orijinal ölçek yapısı ve ifadelerin bir aradaki durumları dikkate alınarak "bedensel değişim", "psikososyal kayıp", "örnek olma" ve "kişisel memnuniyet" şeklinde isimlendirilmesine karar verilmiştir (bkz. Tablo 2).

Tablo 2: Yaşlılık Tutumu Ölçeğine İlişkin Keşfedici Faktör Analizi Sonuçları

\begin{tabular}{llll}
\hline Faktör & Kod & Soru/ifade & $\begin{array}{c}\text { Faktör } \\
\text { Yükü }\end{array}$ \\
\hline & A14 & Yaşımdan beklediğimden daha fazla enerjim var. & 0,751 \\
& A24 & $\begin{array}{l}\text { Egzersiz yaparak kendimi mümkün olduğu kadar dinç ve canlı } \\
\text { tutuyorum. }\end{array}$ & 0,663 \\
& A13 & Kimliğimi sahip olduğum yaş belirlemez. & 0,615 \\
Bedensel değişim & A11 & Kendimi yaşlı hissetmiyorum. & 0,605 \\
& A23 & Sağlığım bu yaşımda beklediğimden daha iyi. & 0,591 \\
& A7 & Her yaşta egzersiz yapmak (hareket etmek, spor yapmak) & 0,520 \\
\hline & O222 & Yaşımlidir. & hissediyorum. \\
& & Yaşlı olduğum için şimdi kendimi toplumun içinde & 0,741 \\
Psikososyal kayıp & hissetmiyorum. & 0,712 \\
& A17 & Yaşlanınca yeni arkadaşlar bulmak daha zor oldu. & 0,597 \\
& A3 & Yaşlılık yalnızlık zamanıdır. & 0,518 \\
\hline
\end{tabular}

Trakya Üniversitesi Iktisadi ve Idari Bilimler Fakültesi e-Dergi, 10, 2021/2, s. 112-129 


\begin{tabular}{llll}
\multirow{2}{*}{ Örnek olma } & A18 & $\begin{array}{l}\text { Tecrübelerimle kazandıklarımı gençlere aktarmak çok } \\
\text { önemlidir. }\end{array}$ & 0,860 \\
& A21 & Gençlere iyi örnek olmak istiyorum. & 0,837 \\
\hline \multirow{2}{*}{ Kişisel } & A2 & Yaşlanmak bir ayrıcalıktır. & 0,740 \\
memnuniyet & A1 & İnsanlar yaşlandıkça yaşamla daha iyi başa çıkabilir. & 0,642 \\
& A5 & Yaşlanıyor olmakla ilgili pek çok hoşa giden (güzel) şey vardır. & 0,630 \\
\hline
\end{tabular}

Toplam Açılanan Varyans: \%52,512; KMO: 0,723; Barlett testi $p=0,000<0,05$

Araştırmada "yaşam kalitesi" değişkenini ölçmek amacıyla kullanılan ölçek için uygulanan ilk keşfedici faktör analizinde Barlett testi $p=0,000<0,05, K M O=0,829$ olarak bulunmuştur. Yapılan ilk keşfedici faktör analizi sonucunda beş faktör elde edilmiş ve bu faktörlerin toplam varyansın \%58,351'ini açıkladığı görülmüştür. Ancak elde edilen faktörler ve faktörler altındaki ifadeler değerlendirildiğinde, orijinal ölçek yapısındaki durumları bozan dağılımlar olduğu, bazı ifadelerin birden fazla faktörle yüksek seviyede ilişki gösterdiği, bazı ifadelerin ise düşük faktör yüküne sahip olduğu gözlenmiştir. Buna istinaden ölçek içerisinde yer alan B10, B12, B13, B15 ve B19 kodlu ifadeler sırasıyla analiz dışı bırakılmış ve her seferinde keşfedici faktör analizi yinelenmiştir. Sonuç olarak 19 ifadeden oluşan yaşam kalitesi ölçeği için beş alt faktörden oluşan bir yapının geçerli olduğu değerlendirilmiştir. Bu yapının toplam varyans açıklama oranının \%62,518 olduğu hesaplanmıştır. Elde edilen alt boyutların orijinal ölçek yapısı ve ifadelerin bir aradaki durumları dikkate alınarak "duyusal işlevler", "özerklik", "sosyal katılım”, "ölüm ve ölmek" ve "yakınlık" şeklinde isimlendirilmesine karar verilmiştir (bkz. Tablo 3).

Tablo 3: Yaşam Kalitesi Ölçeğine ilişkin Keşfedici Faktör Analizi Sonuçları

\begin{tabular}{|c|c|c|c|}
\hline Faktör & Kod & Soru/ifade & $\begin{array}{l}\text { Faktör } \\
\text { Yükü }\end{array}$ \\
\hline \multirow{4}{*}{ Ölüm ve ölmek } & B7 & $\begin{array}{l}\text { Ölümünüzü kontrol etme şansınızın bulunmaması sizi ne kadar } \\
\text { korkutuyor? }\end{array}$ & 0,897 \\
\hline & B8 & Ölmekten ne kadar korkuyorsunuz? & 0,873 \\
\hline & B6 & Nasıl öleceğiniz konusunda ne kadar kaygılısınız? & 0,824 \\
\hline & B9 & Ölmeden önce acı çekmekten ne kadar korkarsınız? & 0,746 \\
\hline \multirow{4}{*}{ Yakınlık } & B24 & İnsanlar tarafından sevilme imkanınız ne kadar oluyor? & 0,806 \\
\hline & B22 & Hayatınızda sevgiyi ne derece yaşıyor ve hissedebiliyorsunuz? & 0,800 \\
\hline & $\mathrm{B} 23$ & İnsanları sevebilme imkanınız ne kadar oluyor? & 0,800 \\
\hline & B21 & $\begin{array}{l}\text { Yaşamınızdaki dostluk ve arkadaşlık duygusunu ne kadar } \\
\text { yaşıyorsunuz }\end{array}$ & 0,715 \\
\hline \multirow{3}{*}{ Duyusal işlevler } & B1 & $\begin{array}{l}\text { Duyularınızdaki (işitme, görme, tat alma, koklama, dokunma) } \\
\text { bozulma günlük yaşamınızı ne ölçüde etkilemektedir? } \\
\text { İşitme, görme, tat alma, koklama ve dokunma duyularınızdaki }\end{array}$ & 0,890 \\
\hline & B2 & $\begin{array}{l}\text { kayıplar sizin günlük faaliyetlere katılabilmenizi ne ölçüde } \\
\text { etkilemektedir? }\end{array}$ & 0,887 \\
\hline & B20* & $\begin{array}{l}\text { Duyularınızla ilgili işlevleriniz (işitme, görme, tat alma, } \\
\text { koklama, dokunma gibi) sizce nasıldır? }\end{array}$ & 0,735 \\
\hline \multirow{3}{*}{ Sosyal katılım } & B17 & Yaptığınız faaliyetlerin miktarından ne kadar hoşnutsunuz? & 0,780 \\
\hline & B16 & Zamanınızı kullanma biçiminizden ne kadar hoşnutsunuz? & 0,686 \\
\hline & B18 & $\begin{array}{l}\text { Toplumsal faaliyetlere katılma imkanlarınızdan ne kadar } \\
\text { hoşnutsunuz? }\end{array}$ & 0,626 \\
\hline
\end{tabular}

Trakya Üniversitesi Iktisadi ve Idari Bilimler Fakültesi e-Dergi, 10, 2021/2, s. 112-129 


\begin{tabular}{|c|c|c|c|}
\hline & B14 & $\begin{array}{l}\text { Ne ölçüde, her gün yeterince yapacak işinizin olduğunu } \\
\text { düşünüyorsunuz? }\end{array}$ & 0,592 \\
\hline \multirow{4}{*}{ Özerklik } & B11 & Yapmak istediklerinizi ne ölçüde yapabildiğiniz inancındasınız? & 0,678 \\
\hline & B4 & Geleceğinizi ne ölçüde kontrol ettiğiniz inancındasınız? & 0,656 \\
\hline & B3 & $\begin{array}{l}\text { Kendi kararlarınızı kendinizin vermesi konusunda ne kadar } \\
\text { özgürsünüz? }\end{array}$ & 0,648 \\
\hline & B5 & $\begin{array}{l}\text { Çevrenizdeki kişilerin sizin özgürlüğünüze saygı gösterdiği } \\
\text { kanısında mısınız? }\end{array}$ & 0,590 \\
\hline
\end{tabular}

Toplam Açıklanan Varyans: \%62,518; KMO: 0,773; Barlett testi $p=0,000<0,05$

* işaretli ifade ters kodlanmıştır.

Keşfedici faktör analizleri sonucunda elde edilen faktörleri oluşturan ifadelerin ortalaması alınarak, bu faktörleri temsil eden değişkenler elde edilmiştir. Araştırmanın hipotezlerini test etmek için uygulanan analizlerde yaşlılık tutumu ve yaşam kalitesi ana değişkenleri yerine, keşfedici faktör analizleri sonucunda elde edilen alt değişkenler kullanılmıştır. Söz konusu değişkenler açısından ise araştırmanın hipotezlerinin her biri için ayrı ayrı alt hipotezler oluşturulmuş ve analizlerde bu alt hipotezler sınanmıştır.

Araştırma hipotezleri sınanmadan önce keşfedici faktör analizleri sonucunda elde edilen değişkenlerin dağılımının normal dağılıma uyup uymadığı değerlendirilmiştir. Bu kapsamda KolmogorovSmirnov ve Shapiro-Wilk testleri kullanılmıştır (bkz. Tablo 4). Her iki test sonucunda da araştırma değişkenlerinin tümünün normal dağılıma uymadığına kanaat getirilmiştir $(p<0,05)$. Buna istinaden araştırma hipotezlerinin testi için parametrik olmayan analizlerden yararlanılmıştır.

Tablo 4: Normallik Testi Sonuçları

\begin{tabular}{lcccccccc}
\hline \multirow{2}{*}{ Değişkenler } & \multirow{2}{*}{ Ort. } & \multirow{2}{*}{ S.S. } & \multicolumn{3}{c}{ Kolmogorov-Smirnov } & \multicolumn{3}{c}{ Shapiro-Wilk } \\
\cline { 5 - 9 } & & & $K S$ & $s d$ & $p$ & $S-W$ & $s d$ & $p$ \\
\hline Bedensel değişim & 3,504 & 0,752 & 0,072 & 408 & 0,000 & 0,987 & 408 & 0,001 \\
Psikososyal kayıp & 2,540 & 0,798 & 0,088 & 408 & 0,000 & 0,979 & 408 & 0,000 \\
Örnek olma & 4,526 & 0,767 & 0,325 & 408 & 0,000 & 0,666 & 408 & 0,000 \\
Kişisel memnuniyet & 3,020 & 0,803 & 0,109 & 408 & 0,000 & 0,977 & 408 & 0,000 \\
Duyusal işlevler & 2,114 & 0,988 & 0,158 & 408 & 0,000 & 0,905 & 408 & 0,000 \\
Özerklik & 3,593 & 0,706 & 0,115 & 408 & 0,000 & 0,958 & 408 & 0,000 \\
Sosyal katılım & 3,176 & 0,795 & 0,109 & 408 & 0,000 & 0,976 & 408 & 0,000 \\
Ölüm ve ölmek & 2,123 & 1,070 & 0,161 & 408 & 0,000 & 0,882 & 408 & 0,000 \\
Yakınlık & 3,853 & 0,769 & 0,148 & 408 & 0,000 & 0,936 & 408 & 0,000 \\
\hline
\end{tabular}

Araştırma hipotezlerinin testi amacıyla Mann-Whitney $U$ testi ve Kruskal Wallis $H$ testi kullanılmıştır. Grup sayısı iki olan cinsiyet, yaşam evresi, çocuk sahibi olma, kronik hastalığa sahip olma durumu ve geleceğe/yaşlılığa yönelik yatırım planı olma durumu değişkenleri için Mann-Whitney U testi kullanılmıştır. Grup sayısı ikiden fazla olan yaş grubu, eğitim düzeyi, medeni durum, gelir durumu, meslek, genel sağlık durumu ve yaşam memnuniyeti değişkenleri için ise Kruskal-Wallis $\mathrm{H}$ testi kullanılmıştır. Bu test sonucunda anlamlı farklılık $(p<0,05)$ bulunması durumunda ise her bir grup için ikili karşılaştırmalar yapılmış ve bunun için Mann-Whitney $U$ testi kullanılmıştır. Söz konusu analiz sonuçlarında elde edilen bulgular özet halde Tablo 5 ve Tablo 6'da raporlanmıştır. 
Tablo 5: Yaşııık Tutumu Puanlarına İlişkin Farklılık Testi Sonuçları (p değerleri)

\begin{tabular}{|c|c|c|c|c|}
\hline \multirow[b]{2}{*}{ Sosyodemografik Değişkenler } & \multicolumn{4}{|c|}{ Yaşlılık Tutumu } \\
\hline & $\begin{array}{l}\text { Bedensel } \\
\text { değişim }\end{array}$ & $\begin{array}{l}\text { Psikososyal } \\
\text { kayıp }\end{array}$ & Örnek olma & $\begin{array}{l}\text { Kişisel } \\
\text { memnuniyet }\end{array}$ \\
\hline Cinsiyet & 0,527 & 0,278 & 0,054 & 0,696 \\
\hline Yaşam Evresi & $0,018^{*}$ & $0,024^{*}$ & 0,251 & 0,629 \\
\hline Yaş Grubu & 0,187 & 0,117 & $0,030^{*}$ & $0,037^{*}$ \\
\hline Eğitim Düzeyi & $0,000^{*}$ & $0,006^{*}$ & 0,868 & 0,293 \\
\hline Medeni Durum & $0,021^{*}$ & 0,057 & 0,199 & 0,817 \\
\hline Çocuk Sahibi Olma & 0,587 & 0,528 & 0,710 & 0,356 \\
\hline Gelir Durumu & $0,000^{*}$ & $0,001^{*}$ & 0,227 & 0,051 \\
\hline Meslek & $0,003^{*}$ & $0,012^{*}$ & $0,002^{*}$ & 0,319 \\
\hline Genel Sağlık Durumu & $0,000^{*}$ & $0,000^{*}$ & $0,010^{*}$ & $0,000^{*}$ \\
\hline Kronik Hastalığa Sahip Olma Durumu & $0,000^{*}$ & $0,017^{*}$ & 0,690 & $0,040^{*}$ \\
\hline Yaşam Memnuniyeti & $0,002^{*}$ & $0,000^{*}$ & $0,003^{*}$ & $0,000^{*}$ \\
\hline $\begin{array}{l}\text { Geleceğe/Yaşlılığa Yönelik Yatırım } \\
\text { Planı Olma Durumu }\end{array}$ & $0,000^{*}$ & $0,009^{*}$ & 0,174 & $0,039^{*}$ \\
\hline
\end{tabular}

Tablo 5 incelendiğinde analiz sonuçları; yaşlılık tutumu alt boyutlarında cinsiyet ve çocuk sahibi olma değişkenleri hariç diğer sosyodemografik değişkenlere göre anlamlı farklılıklar olduğunu göstermiştir. Söz konusu farklılıkların değerlendirmesi çalışmanın sonuç kısmında yapılmıştır.

Tablo 6: Yaşam Kalitesi Puanlarına İlişkin Farklılık Testi Sonuçları (p değerleri)

\begin{tabular}{|c|c|c|c|c|c|}
\hline \multirow[b]{2}{*}{ Sosyodemografik Değişkenler } & \multicolumn{5}{|c|}{ Yaşam Kalitesi } \\
\hline & $\begin{array}{l}\text { Duyusal } \\
\text { işlevler }\end{array}$ & Özerklik & $\begin{array}{l}\text { Sosyal } \\
\text { katılım }\end{array}$ & $\begin{array}{l}\text { Ölüm ve } \\
\text { ölmek }\end{array}$ & Yakınlık \\
\hline Cinsiyet & 0,208 & $0,018^{*}$ & 0,417 & $0,000^{*}$ & $0,037^{*}$ \\
\hline Yaşam Evresi & $0,023^{*}$ & $0,004^{*}$ & 0,199 & 0,852 & $0,035^{*}$ \\
\hline Yaş Grubu & $0,013^{*}$ & $0,013^{*}$ & 0,719 & 0,194 & 0,246 \\
\hline Eğitim Düzeyi & 0,420 & 0,193 & $0,000^{*}$ & 0,747 & 0,498 \\
\hline Medeni Durum & $0,047^{*}$ & 0,797 & 0,093 & 0,267 & $0,001^{*}$ \\
\hline Çocuk Sahibi Olma & 0,198 & 0,921 & 0,727 & 0,664 & 0,631 \\
\hline Gelir Durumu & 0,442 & $0,004^{*}$ & $0,000^{*}$ & 0,277 & $0,019^{*}$ \\
\hline Meslek & 0,640 & $0,000^{*}$ & $0,000^{*}$ & $0,017^{*}$ & 0,237 \\
\hline Genel Sağlık Durumu & $0,000^{*}$ & $0,000^{*}$ & $0,000^{*}$ & 0,207 & $0,000^{*}$ \\
\hline $\begin{array}{l}\text { Kronik Hastalığa Sahip Olma } \\
\text { Durumu }\end{array}$ & $0,048^{*}$ & 0,392 & 0,121 & 0,481 & 0,548 \\
\hline Yaşam Memnuniyeti & $0,011^{*}$ & $0,000^{*}$ & $0,000^{*}$ & 0,554 & $0,000^{*}$ \\
\hline $\begin{array}{l}\text { Geleceğe/Yaşılı̆ı̆a Yönelik } \\
\text { Yatırım Planı Olma Durumu }\end{array}$ & 0,600 & $0,001^{*}$ & $0,000^{*}$ & 0,192 & 0,102 \\
\hline
\end{tabular}

Tablo 6 incelendiğinde analiz sonuçları; yaşam kalitesi alt boyutlarında çocuk sahibi olma değişkeni hariç diğer sosyodemografik değişkenlere göre anlamlı farklılıklar olduğunu göstermiştir. Söz konusu farklııkların değerlendirmesi çalışmanın sonuç kısmında yapılmıştır. 


\section{Sonuç}

Araştırmanın hipotez testi sonuçları incelendiğinde yaşlılık tutumunun cinsiyete göre farklılaşmadığı görülmüştür. Yaşam kalitesi algılamaları açısından ise duyusal işlevler ve sosyal katılım alt boyutlarında cinsiyete göre anlamlı farklılaşma gözlenmezken; özerklik alt boyutunda kadınların sıra ortalamalarının erkeklere kıyasla daha düşük olduğu, ölüm ve ölmek ile yakınlık alt boyutlarında ise daha yüksek olduğu görülmüştür. Bu bulgular Top vd. (2012) ile Sözen vd. (2020) çalışmasındaki bulgularla çoğunlukla benzerlik göstermektedir. Top vd. (2012) yaşlılık tutumunun cinsiyete göre farklılaşmadığını bulmuştur. Sözen vd. (2020) ise yaşlılık tutumunun bedensel değişim boyutunda farklılık olduğunu ve diğer boyutlarda farklılık olmadığını ortaya koymuştur. Bunun yanı sıra Sözen vd. (2020) cinsiyete göre yaşam kalitesinin özerklik, sosyal katılım ve ölüm-ölmek boyutlarının farklılaştığını, yaşam kalitesinin diğer boyutlarında ise farklılık olmadığını ortaya koymuştur. Ortak bulgular göz önünde bulundurularak, cinsiyetin yaşılırın özerklik ve ölüm-ölmek ile ilgili algılamalarını etkileyen bir etmen olduğu, yaşlılığa ilişkin tutumları ise farklılaştırmadığı değerlendirilmiştir.

İçinde bulunulan yaşam evresine göre yaşlıların yaşlılık tutumlarında anlamlı bir farklılaşma olup olmadığına bakıldığında örnek olma ve kişisel memnuniyet açısından istatistiki bir farklılaşma gözlenmezken; bedensel değişimin orta yaş grubunda daha yüksek olması psikososyal kaybın ise yaşlı grupta daha yüksek olması dikkat çekmektedir. Yaşam kalitesi açısından değerlendirildiğinde ise orta yaş grubu ile yaşlı bireyler arasında duyusal işlevler, özerklik ve yakınlık alt boyutlarında anlamlı farklılaşmalar olduğu görülmüştür. Duyusal işlevlerin, özerkliğin ve yakın ilişkilerin yaşlılarda orta yaşlı bireylere kıyasla daha düşük skorlarla değerlendirildiği görülmektedir. Eğitim düzeyine göre bakıldığında yaşlılı tutumunun ve yaşam kalitesine ilişkin değerlendirmelerin mezun olmayanlarla, üniversite ve üzeri eğitim kurumlarından mezun olanlar arasında önemli farklılıklar gösterdiği tespit edilmiştir. Ölçeklerin bedensel değişim, psikososyal kayıp ve sosyal katılım boyutlarında eğitim düzeyinin yükselmesi ile daha olumlu değerlendirmeler yapılmıştır. Medeni duruma göre yaşııık tutumunun bedensel değişim boyutunda evli olanların dul olanlara kıyasla daha yüksek puana sahip olduğu, yaşam kalitesi açısından ise duyusal işlevler ve yakınlık boyutunda farklılıklar olduğu gözlemlenmiştir. Çocuk sahibi olmanın ise bireylerin yaşlılık tutumu ve yaşam kalitesi ile ilgili değerlendirmelerinde farklılaşma oluşturmadığı saptanmıştır. Katılımcıların gelir durumu ile ilgili değerlendirmelerinin yaşlılık tutumu ile ilgili olarak bedensel değişim ve psikososyal kayıp boyutlarında farklılaşma oluşturduğu görülmüştür. Yaşam kalitesi açısından ise otonomi, sosyal katılım ve yakınlık boyutlarında farklılaşma yarattığı gözlemlenmiştir. Kişilerin mesleklerine göre yaşlılık tutumunun bedensel değişim, psikososyal kayıp ve örnek olma boyutlarında farklılık gösterdiği belirlenmiştir. Yaşam kalitesi ile ilgili değerlendirmelerin özerklik, sosyal katılım ve ölümölmek alt boyutlarında mesleğe bağlı olarak farklılaşma gösterdiği görülmüştür. Daha önce yapılan çalışmalardan Top vd. (2012), yaşııık tutumunun okur-yazarlık durumuna ve yaşa göre farklılaştığını, medeni duruma göre farklılık göstermediğini bulmuştur. Sözen vd. (2020) ise yaşlılık tutumunun yaş, medeni durum, eğitim ve çalışma durumuna göre farklııı gösterdiğini; yaşam kalitesinin ise medeni durum, eğitim ve çalışma durumuna göre farklılık gösterdiğini, yaşa göre ise farklılık göstermediğini belirlemiştir. Sonuç olarak bu çalışmada yaş, eğitim düzeyi, medeni durum, gelir durumu ve meslek özelliklerinin yaşlıların yaşam kalitesini ve yaşıııı tutumlarını farklılaştırıcı etmenler olduğu ve elde edilen bulguların yaş ve medeni durum açısından bazı farklılıklar olmakla birlikte Top vd. (2012) ve Sözen vd. (2020)'nin bulgularıyla çoğunlukla uyumlu olduğu değerlendirilmiştir.

Genel sağıı durumu ile ilgili değerlendirmelerin yaşlılık tutumunda önemli ölçüde belirleyici olduğu belirlenmiştir. Yaşlılık tutumunun tüm boyutlarında bir farklılaşma tespit edilmiştir. Farklılaşmaların sağığını "çok iyi" olarak değerlendirenlerle diğer gruplar arasında olması dikkat çekmektedir. Yaşam kalitesi açısından da genel sağlık durumunun önemli bir faktör olduğu görülmüştür. Duyusal işlevler, özerklik, sosyal katılım ve yakınlık alt boyutlarında tespit edilen farklılaşmaların sağlığını 
"çok iyi" ve "iyi" olarak değerlendirenlerle diğer gruplar arasında olduğu görülmüştür. Genel sağlık durumu kadar kronik rahatsızlığa sahip olmanın da yaşlılık tutumunda farklılaşmaya sebep olduğu görülmüştür. Özellikle bedensel değişim, psikososyal kayıp ve kişisel memnuniyet boyutlarındaki farklılaşmalar dikkat çekmektedir. Yaşam kalitesi açısından ise duyusal işlevlerde meydana gelen değişimler kronik rahatsızlığı olanların daha olumsuz değerlendirmelerde bulunmalarına yol açmıştır. Bu bulgularla uyumlu olarak Sözen vd. (2020) de yaşlılarda ilaç kullanım durumunun ve eşlik eden hastalık olması durumunun yaşlılık tutumlarını ve yaşam kalitesi algılamalarını farklılaştırdığını ortaya koymuştur. Yaşamdan mutlu olmanın da yaşlılık tutumunu belirleyen bir faktör olduğu araştırma sonuçlarında gözlemlenmiştir. Yaşlılık tutumunun tüm boyutlarında "çok mutlu" olduğunu belirten bireylerin diğer gruplardan ayrıştığı gözlemlenmiştir. Yaşam kalitesi açısından da yaşamdan mutlu olmanın sonuçları duyusal işlevler, özerklik, sosyal katılım ve yakınlık alt boyutlarında anlamlı farklılaşmalar gösterdiği tespit edilmiştir. Geleceğe/yaşlıığa ait yatırım planı olmasının yaşlııık tutumunda farklılaşmaya sebep olduğu görülmüştür. Araştırmada bedensel değişim, psikososyal kayıp ve kişisel memnuniyet alt boyutlarında yatırım planına sahip olanların daha yüksek puanlara sahip olduğu söylenebilir. Bireylerin geleceğe yönelik yatırım planlarının olması, yaşam kalitesi açısından özerkliği ve sosyal katılımı etkileyen bir faktör olduğu görülmüştür. Top vd. (2012) gerçekleştirdiği çalışmada, hayattan duyulan memnuniyetin ve sosyal güvenliğe sahip olunması durumunun yaşlılık tutumunu farklılaştırdığını tespit etmiştir. Sonuç olarak bu çalışmada genel sağıık durumu, kronik rahatsızlığa sahip olması durumu, yaşamdan duyulan memnuniyet ve gelecek planları olması durumunun yaşlılık tutumunu ve yaşam kalitesi algılamalarını farklılaştıran etmenler olduğu belirlenmiş ve elde edilen bu bulguların daha önceki çalışmaların bulgularıyla uyumlu olduğu değerlendirilmiştir.

Çalışmanın sonuçları bir bütün olarak değerlendirildiğinde; yaşlılık tutumunda ve yaşam kalitesi algısının şekillenmesinde en etkili faktörler sağlık, yaşam memnuniyeti, kronik rahatsızlıklar, eğitim ve gelir olarak sıralanabilir. Türkiye gibi gelişmekte olan ülkelerin çok yakın zamanda "yaşlı bir toplum" olacağı göz önünde bulundurulduğunda, nüfus yapısına uygun uygulamaların kısa bir zaman içerisinde hayata geçirilmesi büyük önem arz etmektedir. Bu anlamda araştırma sonuçlarına ve bu çalışma içerisinde verilen teorik bilgilere dayanarak uygulamalara temel teşkil edecek birtakım öneriler geliştirilebilir. Bu önerilerde ilk sırayı sağıık alanında hayata geçirilecek uygulamalar alacaktır. Zira sağlığa yönelik yatırımlar (özellikle de koruyucu sağlık hizmetleri) ve insanların sağlık açısından bilinçlendirilmesi yaşlıık döneminde karşılaşılacak problemleri en aza indirgeyeceği gibi yaşılık dönemine ilişkin algının da daha olumlu olmasını sağlayacaktır. Ülkemizi sağlık açısından gelişmiş ülkelerle karşılaştıran çalışmalarda Türk toplumunun genel sağlık durumlarının, gelişmiş ülkelerin çok altında olduğu görülmektedir (Eser vd., 2010). Toplum sağlığına ilişkin değerlendirmelerin daha olumlu olması, kronik hastalıklara yakalanma oranının, sürekli ilaç kullanım oranının ve bağımlılık oranının da azalması ile sonuçlanacak dolayısıyla "düşkünlük olarak değerlendirilen" yaşıııı dönemine bakış açısını da daha olumlu değerlendirmelere dönüştürecek etkiye sahiptir.

Yaşlılık döneminin sağlıklı geçirilebilmesine ilişkin eğitimsel faaliyetlerin de önemi azımsanamayacak kadar çoktur. Zira bu araştırmada da düşük eğitim düzeyindeki bireylerin yaşııık tutumu ve yaşam kalitesine ilişkin değerlendirmelerde olumsuz kanaatlerde bulunduğunu göstermiştir. Gerek geriatri gerekse halk sağlığı alanlarında erken yaşlarda doğru beslenme, fiziksel aktivitelerin arttırıması gibi bilinçlendirme çalışmalarının yapılması gelecek nesilleri yaşlılık dönemine hazırlarken hem sağlıklı hem de yaşam memnuniyeti yüksek bir toplum için önem arz etmektedir.

Bireylerin yaşlılık dönemini kendi hanelerinde geçirmek istedikleri bu çalışmada da bir kez daha ortaya konmuştur. Yaşlılık döneminde çocuklarının evlerinde kalmanın pek tercih edilmediği, yaşlı bakım evlerinin ise en son seçenek olarak değerlendirildiği toplumsal yapı çerçevesinde yaşlıların kendi evlerinde 
yaşlanmasına olanak sağlayacak hizmetlerin arttırılması sosyal politikalar açısından daha fazla çalışma gerektiren hususlardan olmuştur.

Yaşlılık dönemine ilişkin belirleyici unsurlardan biri de iktisadi durumdur. Bireyin, ekonomik durumunu, halihazırda yetersiz görmesi onun geleceğe yönelik endişelerinin artmasına neden olacaktır. Emeklilik süreci ile gelirin azalması, bireysel gelir kaynağının olmaması, sağlık harcamalarının bütçe için önemli bir gider haline gelmesi gibi hususlar yaşlılık tutumunda ve yaşam kalitesinde olumsuz değerlendirmelere sebebiyet vermektedir. Bu nedenle gerek ekonomik gerekse sosyal düzenlemeler çerçevesinde yaşlılığın iktisadi güvence altına alınması gerekmektedir.

Üzerinde çokça durulan "yaşııık" için geliştirilecek politikaların uygulanabilirliğinin, sosyokültürel değerlere intibak etmesi ile mümkün olduğu söylenebilir. Yaşlılık döneminin getirileri ile daha evvel tanışan ülkelerin çözüm stratejileri incelenerek ve ülkemizde bu alanda yapılan çalışmalarda ortaya koyulan problemler ve öneriler dikkate alınarak yaşlılığa dair toplumsal ve bireysel olumsuz algıların dönüşümü sağlanabilir.

\section{Araștırmanın Sınırlılıkları}

Bu çalışmanın bazı sınırlılıkları bulunmaktadır. Bunlardan ilki araştırmanın konusunun tüm toplumu değil 45 yaş üstü bireyleri kapsamasıdır. Ayrıca araştırma Ankara'da yaşayan bireyleri kapsaması bakımından sınırlıdır. Yaşlılık tutumu ve yaşam kalitesi değişkenleri için belirlenen ölçme yaklaşımları ile sosyodemografik özellikleri temsilen belirlenen değişkenler açısından da araştırmanın sınırlılıkları bulunmaktadır.

\footnotetext{
| Hakem Değerlendirmesi: Dış bağımsız.

Çıkar Çatışması: Yazar çıkar çatışması bildirmemişsir.

Finansal Destek: Yazar bu çalışma için finansal destek almadığını beyan etmiştir.
}

\section{Kaynakça}

Akçay C. (2013). Yaşlıık: Kavramlar, kuramlar ve yaşlılığa hazırlık (2. Baskı). İstanbul: Kriter Yayınevi.

Akın G., Gültekin T. ve Koca B. (2002). Yaşlı yaşlanmasının evrimsel yönü. Yaşlı Sorunlarını Araştırma Dergisi, 2(1), 57-66.

Altıparmak S. ve Eser E. (2007). 15-49 yaşı ırubu evli kadınlarda yaşam kalitesi. Sosyal Politika Çalışmaları Dergisi, 3(11), 29-33.

Arslan N. (2015). Derin yaşamak (4. Baskı). İstanbul: Sokak Kitapları Yayıncılık.

Bingefors K. ve Isacson D. (2004). Epidemiology, co-morbidity, and Impact on health-related quality of life of self-reported headache and musculoskeletal pain - a gender perspective. European Journal of Pain, 8(5), 435-450.

Boylu A. A. ve Paçacıoğlu B. (2016). Yaşam kalitesi ve göstergeleri. Akademik Araştırmalar ve Çalışmalar Dergisi (AKAD), 8(15), 137-150.

Canatan A. (2008). Sosyal yönleriyle yaşlılık. Ankara: Palme Yayıncılık.

Cummins R. A. (2005). Moving from the quality of life concept to a theory. Journal of Intellectual Disability Research, 49(10), 699-706. 
Çağlar T. (2015). Refah devleti bağlamında almanya'da yaşlılara ilişkin temel haklar. Cumhuriyet Üniversitesi Sosyal Bilimler Dergisi, 39(2), 225-243.

Çolak M. ve Özer Y. E. (2015). Sosyal politika anlamında aktif yaşlanma politikalarının ulusal ve yerel düzeydeki analiz. Elektronik Sosyal Bilimler Dergisi, 14(55), 115-124.

Danış M. Z. (2004). Yaşlıların evde bakım gereksinimleri ve evde bakıma ilişkin düşünceleri. Ankara: GüçVak Yayınları.

Dumuid D., Olds T., Lewis L. K., Martin-Fernández J. A., Katzmarzyk P. T., Barreira T., ... ve Kuriyan R. (2017). Health-related quality of life and lifestyle behavior clusters in school-aged children from 12 countries. The Journal of Pediatrics, 183, 178-183.

Eser E., Fidaner H., Fidaner C., Eser S. Y., Elbi H., ve Göker E. (1999). WHOQOL-100 ve WHOQOL-BREF'in psikometrik özellikleri. Psikiyatri Psikoloji Psikofarmakoloji (3P) Dergisi, 7(2), 23-40.

Eser E., Saatli Gerçeklioğlu G., Eser S. Fidaner C., Baysan P., Pala T. ve Dündar P. (2011), Dünya Sağlık Örgütü - 'Avrupa yaşlanma tutumu anketi (AAQ)' Türkçe sürümünün (AYTA-TR) psikometrik özellikleri. Turkish Journal of Geriatrics, 14(2), 101-110.

Eser S., Saatli G., Eser E., Baydur H. ve Fidaner C. (2010). Yaşlılar için Dünya Sağlık Örgütü yaşam kalitesi modülü WHOQOL-OLD: Türkiye alan çalışması Türkçe sürüm geçerlilik ve güvenilirlik sonuçları. Türk Psikiyatri Dergisi, 21(1), 37-48.

Gill T. M. ve Feinstein A. R. (1994). A critical appraisal of the quality of quality-of-life measurements. JAMA, 272(8), 619-626.

Gursoy-Cuhadar, S. (2020). Yaşlanan nüfusa çözüm önerisi olarak aktif yaşlanma yaklaşımı: eleştiriler ve olası endeks için Türkiye önerileri. Sosyal Siyaset Konferans/arı Dergisi, 79, 361-397.

Gündoğan N. (2001). İ̧̧ücünün yaşlanması ve işgücü piyasalarına etkileri. Ankara Üniversitesi SBF Dergisi, 56(04), 95-108.

Hablemitoğlu Ş. ve Özmete E.(2010). Yaşı refahı: yaşlılar için sosyal hizmet. Ankara: Kilit Yayınları.

İçli, G. (2016). Sosyal statü ve rol bağlamında yaşlılık. İçinde: Yaşlıık Sosyolojisi, Ceylan H. (ed) ss:41-55. Ankara: Nobel Yayıncilık.

İlhan T. (2013). Orta yetişkinlik döneminde psikososyal ve bilişsel gelişim. Yetişkinlik ve Yaşlılık Gelişimi ve Psikolojisi (2. Baskı), İçinde: Bacanlı H. ve Işık Ş. (ed) ss:239-273. İstanbul: Açılım Kitap.

Karadamar M., Yiğit R. ve Sungur M. A. (2014). Ergenlerin sağlıklı yaşam biçimi davranışlarının değerlendirilmesi. Anadolu Hemşirelik ve Sağlık Bilimleri Dergisi, 17(3), 131-139.

Karataş S. (1990). Yaşlılıkta yaşam doyumu ve etkileyen etmenler. Hacettepe Üniversitesi Sosyal Hizmetler Meslek Yüksek Okulu Dergisi, 8(1-2-3), 105-114.

Kılıç M. (2013). Gerçek Yaşam Tadında: Gelişim Dönemleri 3 - Yetişkinlik ve Yaşlılık. Ankara: Pegem Akademi.

Koç M. (2002). Gelişim psikolojisi açısından yaşlılık döneminde ruhsal gelişim. Erciyes Üniversitesi Sosyal Bilimler Enstitüsü Dergisi, 12, 287-304.

Kurtuluş K. (2010). Araştırma Yöntemleri. İstanbul: Türkmen Kitabevi.

Levy, B., Ashman, O. ve Dror, I. (2000). To be or not to be: The effects of aging stereotypes on the will to live. OMEGA-Journal of Death and Dying, 40(3), 409-420.

Trakya Üniversitesi Iktisadi ve İdari Bilimler Fakültesi e-Dergi, 10, 2021/2, s. 112-129 
Levy, B. R., Hausdorff, J. M., Hencke, R. ve Wei, J. Y. (2000). Reducing cardiovascular stress with positive self-stereotypes of aging. The Journals of Gerontology Series B: Psychological Sciences and Social Sciences, 55(4), 205-213.

Levy, B. R., Slade, M. D., Kunkel, S. R. ve Kasl, S. V. (2002). Longevity increased by positive self-perceptions of aging. Journal of Personality and Social Psychology, 83(2), 261-270.

Miller A. and Dishon S. (2006). Health-related quality of life in multiple sclerosis: The impact of disability, gender and employment status. Quality of Life Research, 15(2), 259-271.

OECD (2016). OECD Economic Surveys: Turkey 2016. (Çevrimiçi). https://www.oecd.org/eco/surveys/turkey-2016-OECD-economic-survey-overview.pdf, 13.03.2019.

OECD (2017). OECD better life index: Life satisfaction. (Çevrimiçi). http://www.oecdbetterlifeindex.org/topics/life-satisfaction/, 12.03.2019.

Onur B. (1986). Gelişim psikolojisi: Yetişkinlik, yaşlıık, ölüm. Ankara: V Yayınları.

Santrock J. W. (2017). Yaşam Boyu Gelişim Psikolojisi (13. baskıdan çeviri)., Yüksel G. (Çev.Ed). Ankara: Nobel Yayıncilık.

Saha, S., Basu, S. ve Pandit, D. (2020). Identifying Factors Influencing Perceived Quality of Life (QoL) of Indian Elderly: Case Study of Kolkata, India. Social Indicators Research, 1-41.

Sözen, F., Ersoy, K. ve Çolak, M. Y. (2020). Yaşlılarda yaşam kalitesi ve yaşılıık algısı: Başkent Üniversitesi örneği. The Journal of Turkish Family Physician, 11(4), 191-199.

Şahin, D. S., Özer, Ö. ve Yanardağ M. Z. (2019). Perceived social support, quality of life and satisfaction with life in elderly people. Educational Gerontology, 45(1), 69-77.

Şentürk Ü. (2018). Yaşlıık sosyolojisi: Yaşlılığın toplumsal yörüngeleri. Bursa: Dora Yayıncılık.

Top, M., Eriş, H. ve Kabalcıoğlu, F. (2012). Quality of Life (QOL) and Attitudes Toward Aging in Older Adults in Şanlıurfa, Turkey. Research on Aging, 35(5), 533-562.

Tufan i. (2015). Türkiye'de yaşlıığın yapısal değişimi. İstanbul: Koç Üniversitesi Yayınları.

Tüik (2018). İstatistiklerle yaşlılar 2017. Tüik Haber Bülteni, Sayı: 27595, (Çevrimiçi) www.tuik.gov.tr/PdfGetir.do?id=27595, 15.03.2019.

UN (2016). Demographic yearbook - 2015. New York: United Nations Department of Economic and Social Affairs.

UN (2017). World population prospects: The 2017 revision. New York: United Nations Department of Economic and Social Affairs.

Uysal V. (2006). Türkiye'de dindarlık ve kadın. İstanbul: Dem Yayınları.

Veenhoven R. (2013). The four qualities of life ordering concepts and measures of the good life. The Exploration of Happiness: Happiness Studies Book Series, In Delle Fave A. (ed) pp:195-226. New York: Springer.

WHO (1997). WHOQOL: Measuring Quality of Life. Switzerland: World Health Organisation.

WHO (2002). Active Ageing: a Policy Framework. Switzerland: World Health Organization.

WHO (2015). World Report on Ageing and Health 2015. Switzerland: World Health Organization.

Trakya Üniversitesi Iktisadi ve Idari Bilimler Fakültesi e-Dergi, 10, 2021/2, s. 112-129 
Yıldız R., Ömeroğlu G. ve Terim N. (2017). Yaşlı penceresinden yaşlı ayrımcılığı: Bursa ve Yalova Örneği. Ahi Evran Üniversitesi Sosyal Bilimler Enstitüsü Dergisi, 3(2), 313-329.

Yoğurtçu, G. (2019). Yaşlıık Olgusu ve Yaşlıığın Medyada Temsili: Türkiye, Rusya ve Kırgızistan Gazeteleri Örneği. Atatürk Üniversitesi Sosyal Bilimler Enstitüsü Dergisi, 23 (3) , 1049-1066. 